\title{
TU/e emonowne

\section{Strain-driven alignment of in nanocrystals on InGaAs quantum dot arrays and coupled plasmon-quantum dot emission}

\section{Citation for published version (APA):}

Urbanczyk, A. J., Hamhuis, G. J., \& Nötzel, R. (2010). Strain-driven alignment of in nanocrystals on InGaAs quantum dot arrays and coupled plasmon-quantum dot emission. Applied Physics Letters, 96(11), 113101-1/3. [113101]. https://doi.org/10.1063/1.3358122

DOI:

10.1063/1.3358122

Document status and date:

Published: 01/01/2010

\section{Document Version:}

Publisher's PDF, also known as Version of Record (includes final page, issue and volume numbers)

\section{Please check the document version of this publication:}

- A submitted manuscript is the version of the article upon submission and before peer-review. There can be important differences between the submitted version and the official published version of record. People interested in the research are advised to contact the author for the final version of the publication, or visit the $\mathrm{DOI}$ to the publisher's website.

- The final author version and the galley proof are versions of the publication after peer review.

- The final published version features the final layout of the paper including the volume, issue and page numbers.

Link to publication

\section{General rights}

Copyright and moral rights for the publications made accessible in the public portal are retained by the authors and/or other copyright owners and it is a condition of accessing publications that users recognise and abide by the legal requirements associated with these rights.

- Users may download and print one copy of any publication from the public portal for the purpose of private study or research.

- You may not further distribute the material or use it for any profit-making activity or commercial gain

- You may freely distribute the URL identifying the publication in the public portal.

If the publication is distributed under the terms of Article 25fa of the Dutch Copyright Act, indicated by the "Taverne" license above, please follow below link for the End User Agreement:

www.tue.nl/taverne

Take down policy

If you believe that this document breaches copyright please contact us at:

openaccess@tue.nl

providing details and we will investigate your claim. 


\title{
Strain-driven alignment of In nanocrystals on InGaAs quantum dot arrays and coupled plasmon-quantum dot emission
}

\author{
A. Urbańczyk, a) G. J. Hamhuis, and R. Nötzel \\ Department of Applied Physics, COBRA Research Institute on Communication Technology, \\ Eindhoven University of Technology, 5600 MB Eindhoven, The Netherlands
}

(Received 12 January 2010; accepted 18 February 2010; published online 15 March 2010)

\begin{abstract}
We report the alignment of In nanocrystals on top of linear InGaAs quantum dot (QD) arrays formed by self-organized anisotropic strain engineering on GaAs (100) by molecular beam epitaxy. The alignment is independent of a thin GaAs cap layer on the QDs revealing its origin is due to local strain recognition. This enables nanometer-scale precise lateral and vertical site registration between the QDs and the In nanocrystals and arrays in a single self-organizing formation process. The plasmon resonance of the In nanocrystals overlaps with the high-energy side of the QD emission leading to clear modification of the QD emission spectrum. () 2010 American Institute of Physics. [doi:10.1063/1.3358122]
\end{abstract}

Coupling of a semiconductor quantum dot (QD) to an electromagnetic resonator is of fundamental interest to control its optical properties. The system most widely studied is a QD placed in a photonic crystal cavity. ${ }^{1-3}$ More recently, the coupling of a QD to the plasmon resonance of a metal nanoparticle or nanoparticle array has attracted much attention, representing the ultimate electromagnetic resonator with subwavelength size. Such hybrid QD-metal nanoparticle structures enable the enhancement of the QD emission, ${ }^{4-7}$ control of the polarization of emitted light, ${ }^{8}$ modification of the far field radiation pattern, ${ }^{9}$ and other interesting collective optical phenomena. ${ }^{10,11}$ So far, fabricating those structures relied on chemical self-assembly ${ }^{12}$ or top-down processing, ${ }^{8}$ the latter being without control of the position of the QDs with respect to the metal nanostructures which is required to fully exploit their unique properties.

In this work, we report the alignment of In nanocrystals on one-dimensional (1D) InGaAs QD arrays formed by selforganized anisotropic strain engineering on $\mathrm{GaAs}$ (100) by molecular beam epitaxy (MBE). The In nanocrystals grow on top of the QD arrays which are uncapped or capped with a thin GaAs layer, indicating strain driven nucleation. By controlling the growth parameters such as In amount and growth temperature, dilute In nanocrystal arrangements or 1D arrays of closely spaced In nanocrystals following the underlying 1D InGaAs QD arrays with different size are realized. Hence, nanometer-scale precise lateral (due to the ordered QD arrays) as well as vertical (due to the GaAs cap layer thickness) site registration between the QDs and the In nanocrystals and arrays is achieved in a single, selforganizing epitaxial growth process. The plasmon resonance of the In nanocrystals overlaps with the high-energy side of the QD emission, leading to clear modification of the photoluminescence (PL) spectra due to coupled plasmon-QD emission in temperature dependent measurements.

The samples were grown by solid source MBE on undoped, singular GaAs (100) substrates. After native oxide removal under $\mathrm{As}_{4}$ flux at $580{ }^{\circ} \mathrm{C}$, a $200 \mathrm{~nm}$ thick GaAs buffer layer was grown. Next, a 15 -periods InGaAs/GaAs

\footnotetext{
a) Author to whom correspondence should be addressed. Electronic mail: a.j.urbanczyk@tue.nl.
}

superlattice (SL) template was grown for $1 \mathrm{D}$ QD ordering on top. ${ }^{13}$ Each SL period consisted of a $2.3 \mathrm{~nm} \mathrm{In}_{0.4} \mathrm{Ga}_{0.6} \mathrm{As}$ QD layer grown at $540{ }^{\circ} \mathrm{C}$ immediately capped with $0.7 \mathrm{~nm}$ GaAs, annealing for $2 \mathrm{~min}$ at $580{ }^{\circ} \mathrm{C}$, and a $12 \mathrm{~nm}$ GaAs layer grown at $580{ }^{\circ} \mathrm{C}$. On the SL template a single layer of $2.3 \mathrm{~nm} \mathrm{In}_{0.4} \mathrm{Ga}_{0.6} \mathrm{As}$ QDs was deposited, either left uncapped or capped with 1 or $3 \mathrm{~nm} \mathrm{GaAs}$. After this the samples were cooled down to 100 or $120{ }^{\circ} \mathrm{C}$ and In nanocrystals with 4 or 12 monolayers (ML) In amount were deposited. ${ }^{14}$ The growth rates for GaAs and InAs were 0.054 and 0.0375 $\mathrm{nm} / \mathrm{s}$. The surface morphology of the In nanocrystals was characterized by tapping-mode atomic force microscopy (AFM) in air. For temperature dependent PL measurements of the InGaAs QD arrays the samples were placed in a Heflow cryostat. A frequency doubled neodymium-doped yttrium aluminum garnet (Nd:YAG) laser (532 $\mathrm{nm}$ line) was used as an excitation source with excitation power density of $256 \mathrm{~mW} / \mathrm{cm}^{2}$. The PL was dispersed by a single $1 / 4-\mathrm{m}$ monochromator and detected by a liquid nitrogen cooled InGaAs photodiode array. The plasmon response of the In nanocrystals was measured by differential reflectivity (DR) spectroscopy at room temperature. ${ }^{15}$ The DR setup consisted of a halogen light source, a double 1/4-m monochromator, and $\mathrm{a} \mathrm{PbS}$ detector.

Figure 1 shows the AFM images of the In nanocrystals for different deposition conditions, i.e., In amount and growth temperature, and GaAs cap layer thickness on the InGaAs QD arrays as follows: (a) $4 \mathrm{ML}$ In, $100{ }^{\circ} \mathrm{C}$, no GaAs cap; (b) $12 \mathrm{ML}$ In, $100{ }^{\circ} \mathrm{C}$, no GaAs cap; (c) $4 \mathrm{ML}$ In, $120{ }^{\circ} \mathrm{C}$, no GaAs cap; (d) 4 ML In, $120^{\circ} \mathrm{C}$, 1 -nm GaAs cap; (e) 4 ML In, $120^{\circ} \mathrm{C}$, 3-nm GaAs cap; and (f) $12 \mathrm{ML}$ In, $120^{\circ} \mathrm{C}$, no GaAs cap. The general trend from (a) to (f) is an increase in nanocrystal density and size with In amount and a decrease in nanocrystal density and increase in size with growth temperature, similar to the direct growth on GaAs (100). ${ }^{14}$ Most important, in all cases the In nanocrystals align on top of the InGaAs QDs leading to correlated dilute nanocrystal arrangements for smaller In amount and higher growth temperature [most pronounced in Fig. 1(e)] and to ordered 1D arrays of closely spaced In nanocrystals for larger In amount and lower growth temperature [most pronounced in Fig. 1(b)]. The correlated In nanocrystal growth 

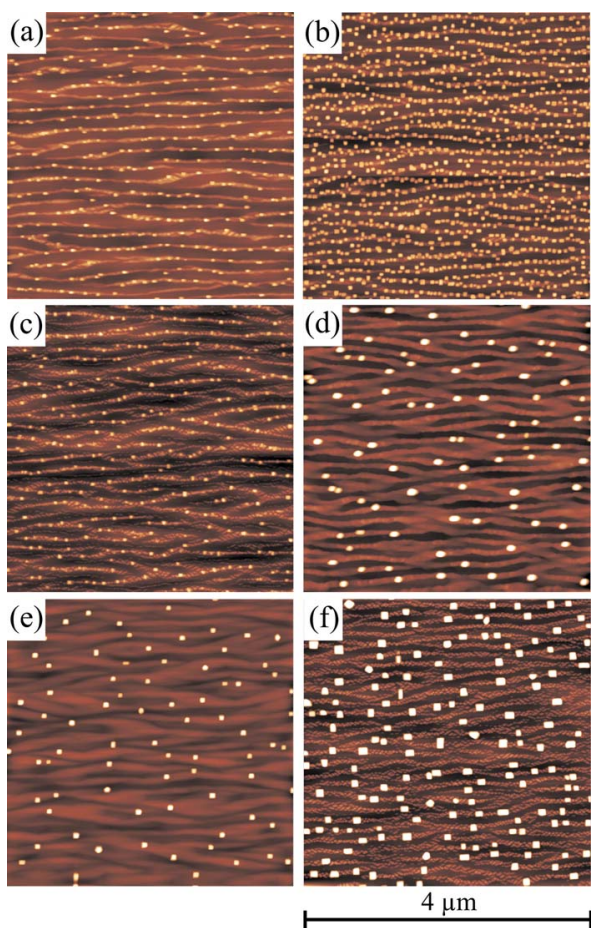

FIG. 1. (Color online) AFM images of the In nanocrystals with different In amount, growth temperature, and GaAs cap layer thickness on the InGaAs QD arrays: (a) $4 \mathrm{ML}$ In, $100{ }^{\circ} \mathrm{C}$, no GaAs cap; (b) $12 \mathrm{ML}, 100{ }^{\circ} \mathrm{C}$, no GaAs cap; (c) $4 \mathrm{ML}, 120{ }^{\circ} \mathrm{C}$, no GaAs cap; (d) $4 \mathrm{ML}, 120^{\circ} \mathrm{C}$, 1-nm GaAs cap; (e) $4 \mathrm{ML}, 120^{\circ} \mathrm{C}, 3-\mathrm{nm}$ GaAs cap; and (f) $12 \mathrm{ML}, 120^{\circ} \mathrm{C}$, no GaAs cap. The AFM scan fields are $4 \times 4 \mu \mathrm{m}^{2}$.

is preserved in the presence of the GaAs cap layer on the InGaAs QDs [Figs. 1(d) and 1(e)] although the surface smoothens with increasing cap layer thickness (height modulation of $7 \mathrm{~nm}$ without GaAs cap and of $5 \mathrm{~nm}$ with 3-nm GaAs cap). This indicates that the alignment is not due to morphological features but due to strain mediated nucleation similar to the case of the InGaAs QDs. This is attributed to the crystalline nature of the In nanocrystals with the shape of a truncated pyramid and a clear epitaxial relationship with the GaAs (100) surface. ${ }^{14}$

Figure 2 shows the temperature dependent PL spectra of the InGaAs QD arrays capped with 3-nm GaAs and 4 ML In nanocrystals grown at $120^{\circ} \mathrm{C}$ on top. The average base size and height of the In nanocrystal grown under these conditions are 40 and $30 \mathrm{~nm}$, respectively, and their density is $5.1 \mu^{-2}$. The peak centered at low temperature at $1.04 \mathrm{eV}$ is from the QDs and that centered at $1.31 \mathrm{eV}$ is from the SL template. As always observed, the PL from the SL template vanishes with increasing temperature due to thermally activated carrier transfer from the SL template to the QDs. At elevated temperature an additional peak centered at $1.21 \mathrm{eV}$ becomes evident, most clearly at $120 \mathrm{~K}$, shown in the upper inset in Fig. 2, which is detected up to room temperature. Such emission is not observed for the InGaAs QD arrays without In nanocrystals on top, as seen in the PL spectrum denoted as ref in Fig. 2, taken at room temperature. The PL peak coincides in energy with the plasmon resonance of the In nanocrystals determined from the DR measurements at room temperature, shown in the lower inset in Fig. 2.

We assign the PL peak of the InGaAs QD arrays centered at $1.21 \mathrm{eV}$ to coupled surface plasmon resonance (SPR)-QD emission, which manifests itself in the resonant

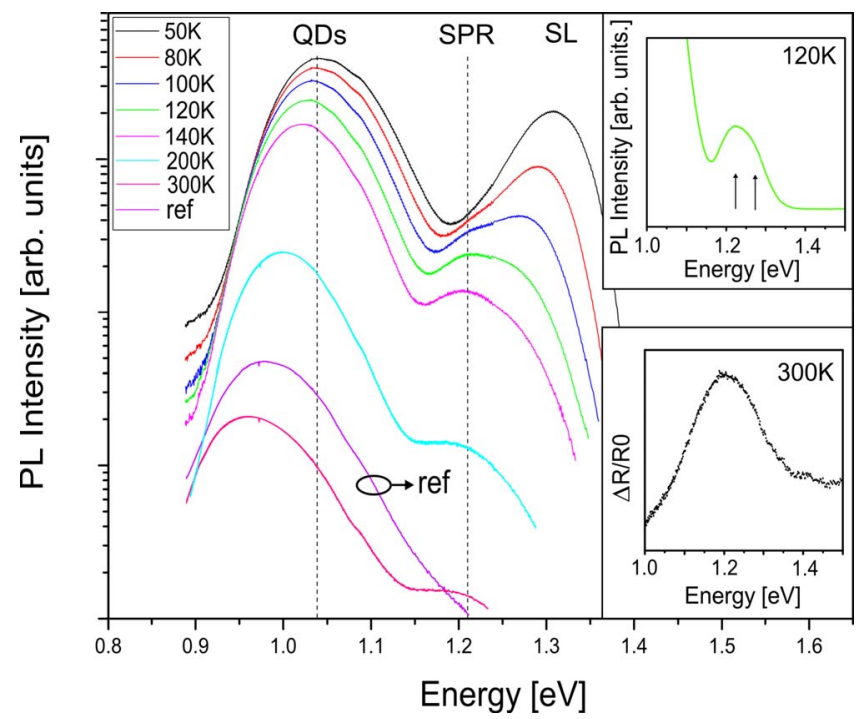

FIG. 2. (Color online) Temperature dependent PL spectra of the InGaAs QD arrays capped with $3 \mathrm{~nm}$ GaAs and $4 \mathrm{ML}$ In nanocrystals grown at $120{ }^{\circ} \mathrm{C}$ on top in logarithmic scale. The lines are guides for the eyes. The spectrum marked as ref is a reference room temperature measurement of a structure without In on top. Upper inset: $120 \mathrm{~K} \mathrm{PL} \mathrm{spectrum} \mathrm{in} \mathrm{linear} \mathrm{scale.} \mathrm{Lower}$ inset: DR spectrum of the In nanocrystals taken at room temperature.

enhancement of the PL efficiency, although the overall PL intensity of the QDs is reduced in the presence of the In nanocrystals. Coupled SPR-QD emission is supported by the small low-energy shift with increasing temperature (due to the small change in the refractive index of GaAs, slightly redshifting the SPR with temperature) compared to the much larger low-energy shift of the QD PL (due to the temperature dependent shrinkage of the GaAs band gap energy and carrier delocalization). At the lowest temperatures the SPR enhanced emission overlaps with the SL template PL and can therefore not be identified, although it increases in intensity due to lower resistive losses in the In nanocrystals. SPR enhanced emission of the SL template is not expected due to its larger separation from the In nanocrystals together with the large refractive index of GaAs. DR measurements of randomly distributed In nanocrystals directly grown on GaAs (100), not shown here, reveal SPRs in the same energy range which distinctly redshift with increasing nanocrystal size. However, their inhomogeneous broadening is much larger$0.6 \mathrm{eV}$ versus $0.2 \mathrm{eV}$ for the ordered In nanocrystals for the same growth conditions due to a much larger In nanocrystal size dispersion. Such a broad resonance would not allow the identification of coupled SPR-QD emission in the spectral shape as is the case for the broader SPR of dense In nanocrystal arrangements.

In conclusion, we have demonstrated the alignment of In nanocrystals on linear InGaAs QD arrays formed by selforganized anisotropic strain engineering on GaAs (100) by MBE. The In nanocrystals grow on top of the QD arrays, which were uncapped or capped with a thin GaAs layer due to strain driven nucleation. By controlling the growth parameters such as In amount and growth temperature, dilute In nanocrystal arrangements or 1D arrays of closely spaced In nanocrystals with different size were realized. Hence, nanometer-scale precise lateral as well as vertical site registration between the QDs and the In nanocrystals and arrays was achieved in a single self-organizing formation process. The SPR of the In nanocrystals overlaps with the high- 
energy side of the QD emission which leads to clear modification of the PL spectrum evidencing coupling between the QDs and localized SPRs of the In nanocrystals.

${ }^{1}$ D. Englund, D. Fattal, E. Waks, G. Solomon, B. Zhang, T. Nakaoka, Y. Arakawa, Y. Yamamoto, and J. Vučković, Phys. Rev. Lett. 95, 013904 (2005).

${ }^{2}$ A. Badolato, K. Hennessy, M. Atature, J. Dreiser, E. Hu, P. M. Petroff, and A. Imamoglu, Science 308, 1158 (2005).

${ }^{3}$ A. Kress, F. Hofbauer, N. Reinelt, M. Kaniber, H. J. Krenner, R. Meyer, G. Bohm, and J. J. Finley, Phys. Rev. B 71, 241304 (2005).

${ }^{4}$ O. Kulakovich, N. Strekal, A. Yaroshevich, S. Maskevich, S. Gaponenko, I. Nabiev, U. Woggon, and M. Artemyev, Nano Lett. 2, 1449 (2002).

${ }^{5}$ J. S. Biteen, N. S. Lewis, H. A. Atwater, H. Mertens, and A. Polman, Appl. Phys. Lett. 88, 131109 (2006).

${ }^{6}$ J. S. Biteen, D. Pacifici, N. S. Lewis, and H. A. Atwater, Nano Lett. 5, 1768 (2005).
${ }^{7}$ V. K. Komarala, Y. P. Rakovich, A. L. Bradley, S. J. Byrne, Y. K. Gun'ko, N. Gaponik, and A. Eychmuller, Appl. Phys. Lett. 89, 253118 (2006).

${ }^{8}$ H. Mertens, J. S. Biteen, H. A. Atwater, and A. Polman, Nano Lett. 6, 2622 (2006).

${ }^{9}$ L. A. Blanco and F. J. Garcia de Abajo, Phys. Rev. B 69, 205414 (2004). ${ }^{10}$ W. Zhang, A. O. Govorov, and G. W. Bryant, Phys. Rev. Lett. 97, 146804 (2006).

${ }^{11}$ V. K. Komarala, A. L. Bradley, Y. P. Rakovich, S. J. Byrne, Y. K. Gun'ko, and A. L. Rogach, Appl. Phys. Lett. 93, 123102 (2008).

${ }^{12}$ T. Pons, I. L. Medintz, K. E. Sapsford, S. Higashiya, A. F. Grimes, D. S. English, and H. Mattoussi, Nano Lett. 7, 3157 (2007).

${ }^{13}$ T. Mano, R. Nötzel, G. J. Hamhuis, T. J. Eijkemans, and J. H. Wolter, J. Appl. Phys. 95, 109 (2004).

${ }^{14}$ A. Urbańczyk, G. J. Hamhuis, and R. Nötzel, J. Appl. Phys. 107, 014312 (2010).

${ }^{15}$ R. Lazzari, S. Roux, I. Simonsen, J. Jupille, D. Bedeaux, and J. Vlieger, Phys. Rev. B 65, 235424 (2002). 